\title{
Efficacy of new herbicide (bispyribac sodium $10 \%$ SC) against different weed flora, nutrient uptake in rice and their residual effects on succeeding crop of green gram under zero tillage
}

\author{
S .T. Kumaran ${ }^{* 1}$, G. Kathiresan ${ }^{1}$, P. Murali Arthanari ${ }^{1}$, C. Chinnusamy ${ }^{1}$ and V. Sanjivkumar ${ }^{2}$ \\ ${ }^{1}$ Department of Agronomy, Tamil Nadu Agricultural University, Coimbatore -641003, (Tamil Nadu), INDIA. \\ ${ }^{2}$ Department of Soil Science, Tamil Nadu Agricultural University, Coimbatore -641003, (Tamil Nadu), INDIA. \\ *Corresponding author. E-mail: kumaran.agri@gmail.com
}

Received: May 23, 2014; Revised received: January 24, 2015; Accepted: April 16, 2015

\begin{abstract}
Field experiment was conducted in the wetland farms of Tamil Nadu Agricultural University, Coimbatore during rabi season (August to February) of 2011-12 to evaluate the herbicide (Bispyribac sodium 10\% SC) on weed control and their nutrient management in direct seeded lowland rice. The experiment was laid out in a Randomized Block Design (RBD) with three replications. The results revealed that Early Post Emergence (EPOE) application of bispyribac sodium 10\% SC $40 \mathrm{~g} \mathrm{ha}^{-1}$ recorded higher weed control efficiency and lesser weed density, nutrient uptake at reproductive stage of the crop. Different weed management practices imposed on rice crop did not affect the germination of succeeding green gram.
\end{abstract}

Key words: Early post emergence, Rice, Soluble concentration, Weed management

\section{INTRODUCTION}

Rice (Oryza sativa L.) stuff of life, it is necessary to increase its production and productivity in order to meet the growing demands of rice by our increasing population. Rice is grown in an area of 45 million ha annually with a production of 80.14 million tonnes, with an average productivity of $2177 \mathrm{~kg} \mathrm{ha}^{-1}$ during 2009 to 2010 (FAO, 2010). India has to produce 135-145 million tonnes of rice by 2020 to feed the additional 350 million people (Prakash et al., 2008).To sustain present food self-sufficiency and to meet future food requirements, India has to increase its rice productivity by 3 per cent per annum. Generally, the productivity of upland rice is very low owing to heavy weed infestation. Yield loss due to weeds in direct seeded upland rice varied from 40 to $100 \%$ depending on the weed flora, their density and duration of competition (Choubey et al., 2001). Direct-seeding constitutes both wet- and dry -seeding and it does away with the need for seedlings, nursery preparation, uprooting of seedlings and transplanting (Pandey et al., 2010). Weeds were reported to reduce rice yields by 12 to $98 \%$, Moreover, the rice herbicides presently used are mainly pre-emergence and weeds coming at later stages of crop growth are not controlled as effectively as at emergence stage (Yadav et al., 2009). This situation warranted for initiating research works to evaluate and identify suitable post emergence herbicide (s). Use of alternative herbicides that provide wide-spectrum of weed control would be desirable for effective weed control. One of the most important classes of herbicides that have been used popularly all over the world is sulfonylurea group of herbicides. Among several sulfonylurea herbicides, bispyribac sodium is a new post emergence rice herbicide. It is more effective against a broad spectrum of annual and perennial rice weeds. Therefore, the present study was undertaken to evaluate the performance of new post-emergence herbicides, against complex weed flora and nutrient uptake by weeds in direct seeded rice system.

\section{MATERIALS AND METHODS}

Field experiment was conducted in the wetland farms of Tamil Nadu Agricultural University, Coimbatore during rabi season (August to February) of 2011-12. The experiment was laid out in a randomized block design with three replications. The soil fertility status was medium in available nitrogen $\left(234 \mathrm{~kg} \mathrm{ha}^{-1}\right)$, low in available phosphorus $\left(15.8 \mathrm{~kg} \mathrm{ha}^{-1}\right)$ and high in available potassium $\left(467 \mathrm{~kg} \mathrm{ha}^{-1}\right)$. Medium duration rice variety CO (R) 48 used as a test variety in the study. The treatments consist of early post emergence application of bispyribac sodium $10 \% \mathrm{SC}$ at $10,20,40 \mathrm{~g} \mathrm{ha}^{-1}$, nominee gold 20 $\mathrm{g} \mathrm{ha}^{-1}$ on 15 days after sowing and PE application of butachlor $1.5 \mathrm{~kg} \mathrm{ha}^{-1}$, anilophos $0.45 \mathrm{~kg} \mathrm{ha}^{-1}$, pretilachlor $\mathrm{S} 0.45 \mathrm{~kg} \mathrm{ha}^{-1}$ on 3 days after sowing $+\mathrm{HW}$ on 40 days after sowing and power weeder, conoweeder weeding at 20 and 40 days after sowing, HW twice on 20 and 40 days after sowing and unweeded control. A seed rate of $30 \mathrm{~kg} \mathrm{ha}^{-1}$ was adopted. The sprouted seeds were uniformly sowing by manually operated rice drum seeder developed by TNAU, Coimbatore. It 
drops the seeds at $20 \mathrm{~cm}$ apart in continuous row. Careful water management practices were adopted for in the first one week.

Recommended doses of fertilizer of 150:50:50 kg N, $\mathrm{P}_{2} \mathrm{O}_{5}, \mathrm{~K}_{2} \mathrm{O}$ ha $^{-1}$ was adopted. The entire quantity of $\mathrm{P}$ was applied as basal. Nitrogen in the form of urea and potassium as muriate of potash were applied in four equal splits at basal, active tillering, panicle initiation and at flowering stages. The farm yard manure was applied @ $12.5 \mathrm{t} \mathrm{ha}^{-1}$ at last ploughing, incorporated and then leveled as per treatment. The quantity of early post emergence (EPOE) and pre emergence (PE) herbicides calculated as per the treatmental schedule pre emergence (PE) was applied using fan type nozzle (WFN 40) on 3 days after sowing while the new molecular bispyribac sodium $10 \%$ SC, nominee gold was applied as early post emergence herbicides on 12 days after sowing. The herbicides were applied by keeping a thin film of water in the field. The field was neither drained nor irrigated for 2 days after application of herbicides. Hand weeding was given for PE herbicides treated plots on 40 days after sowing. The unweeded control plots were kept undisturbed for the entire cropping period.

\section{RESULTS AND DISCUSSION}

\section{Weed characters}

Weed flora of the experimental field: The common weed flora of the experimental field consisted of grasses, sedges and broad leaved weeds (BLW). They were observed from the unweeded check plot at flowering stage of the rice crop (Table.1). Among the grasses Echinochloa colona (L) was a dominant one and the major sedge was Cyperus iria (L) and Cyperus difformis (L). Among the broad leaved weeds, Eclipta alba (L), Ammania baccifera (L) and Ludwigia parviflora (L) were the dominant species (Table.1). Such wide spectrum of weeds in direct seeded rice was reported by many workers under puddled conditions (Bayan, 2000; Ravisankar, 2002; Subramanian et al., 2006; Reddy, 2010).

\section{Weed density}

Grasses density: Different weed management practices had significant influence on the total grass weed density. In the early stage (20 DAS) of the crop, intergraded weed management practices (pre-emergence herbicide + hand weeding) lowered the weeds number than other practices (Table.2). It reduced the grasses density significantly, compared to early post-emergence herbicide alone and mechanical control. It was also on par with weed free check. Significant difference was not observed among different treatments with herbicides at this stage.

Similar to 20 DAS, integrated weed management practices registered lesser number of grasses than other practice on 40 DAS. Significantly the lowest number was observed in weed free check. Among the other treatments, early post-emergence herbicide of bispyribac sodium $10 \%$
SC $40 \mathrm{~g} \mathrm{ha}^{-1}\left(\mathrm{~T}_{3}\right)$ had lower weed density (4.97 No. m $\left.{ }^{2}\right)$. On $60 \mathrm{DAS}$, the treatment pretilachlor $\mathrm{S}$ at $0.45 \mathrm{~kg}$ a.i ha ${ }^{-1}+$ one hand weeding on 40 DAS has registered the lowest grasses density $\left(2.59 \mathrm{No} \mathrm{m}^{-2}\right)$. It was on par with weed free check. These treatments caused reduction of grass density significantly over unweeded check. Reddy (2010) reported that application of pretilachlor + safener@0.45 kg ha ${ }^{-1}$ on 3 DAS and conoweeding on 45 DAS has registered excellent control of grass density.

Sedges density: At all the stages of observation viz., 20, 40 and 60 DAS the sedges weed density was lowered by weed free check. In the early stage (20 DAS) of the crop, application of pre-emergence herbicide had influence on lowering the sedges population and in the later stage (40 DAS), weed free check had significantly lowered the number of sedges than all other treatments (Table.2). Among the herbicide treatments, early post-emergence bispyribac sodium $10 \%$ SC $40 \mathrm{~g} \mathrm{ha}^{-1}$ $\left(\mathrm{T}_{3}\right)$ has registered significantly lower population. On 60 DAS, pretilachlor $S$ at $0.45 \mathrm{~kg}$ a.i ha ${ }^{-1}$ followed by one hand weeding on 40 DAS $\left(\mathrm{T}_{7}\right)$ has minimum number of sedges population $\left(2.55 \mathrm{No} . \mathrm{m}^{-2}\right)$ and it was on par with weed free check.

Broad leaved weeds density: Weed control treatments did exert significant influence on the density of broad leaved weeds. In the early stage (20 DAS), the weed free check has registered significantly lesser number of broad leaved weeds than other treatments (Table.2). Among the herbicide treatments, pretilachlor $\mathrm{S}$ at 0.45 $\mathrm{kg}$ a.i ha ${ }^{-1}$ with one hand weeding on 40 DAS $\left(\mathrm{T}_{7}\right)$ was the best treatment to minimize the broad leaved weeds population and it was on par with butachlor $50 \% \mathrm{EW}$ at $1.5 \mathrm{~kg}$ a.i. $\mathrm{ha}^{-1}+\mathrm{HW}$ on $40 \mathrm{DAS}\left(\mathrm{T}_{5}\right)$, anilophos $30 \%$ EC at $0.45 \mathrm{~kg}$ a.i. ha ${ }^{-1}+\mathrm{HW}$ on 40 DAS $\left(\mathrm{T}_{6}\right)$. Similar observation also made by Yadev et al. (2009) who found that, $30-60 \mathrm{~g} \mathrm{ha}^{-1}$ bispyribac sodium applied at 15 DAT were at par with pretilachlor at $1.0 \mathrm{~kg}$ a.i. $\mathrm{ha}^{-1}$ and butachlor at 1.5 a.i. $\mathrm{kg} \mathrm{ha}^{-1}$. At later stage bispyribac sodium $10 \% \mathrm{SC} 40 \mathrm{~g} \mathrm{ha}^{-1}\left(\mathrm{~T}_{3}\right)$ has significantly registered lesser number of broad leaved weeds than other herbicide treatments. However, it was on par with pretilachlor $S$ at $0.45 \mathrm{~kg} \mathrm{a.i} \mathrm{ha}{ }^{-1}+$ one hand weeding on 40 DAS $\left(\mathrm{T}_{7}\right)$. On 60 DAS, weed free check continued to registered lesser number of broad leaved weeds.

Total weed density: Significant variation in total weed density was observed among the weed control treatments. At early stage of crop growth, lesser weed density was observed in the weed free plot (Table.2). Statistically it was on par with the application of preemergence herbicide pretilachlor $S$ at $0.45 \mathrm{~kg}$ a.i ha ${ }^{-1}+$ HW on 40 DAS, butachlor $50 \% \mathrm{EW}$ at $1.5 \mathrm{~kg}$ a.i. $\mathrm{ha}^{-1}$ + HW on 40 DAS and anilophos $30 \%$ EC at $0.45 \mathrm{~kg}$ a.i. $\mathrm{ha}^{-1}+\mathrm{HW}$ on 40 DAS. On 40 and 60 DAS, the total weed density was found to be lesser in weed free treatment and it was on par with application of bispyribac sodium $10 \% \mathrm{SC}$ at $40 \mathrm{~g}$ and pretilachlor $\mathrm{S}$ at $0.45 \mathrm{~kg}$ a.i ha ${ }^{-1}$ followed by one hand weeding on $40 \mathrm{DAS}\left(\mathrm{T}_{7}\right)$. Bispyribac 
Table 1. Weed flora of the experimental field.

\begin{tabular}{clccc}
\hline S. N. & Botanical name & Common name & Life form & Family \\
\hline I. & Grasses & Jungle grass & A & Poaceae \\
1. & Echinochloa colonum $($ L. $)$ Link & Barnyard grass & A & Poaceae \\
2. & Echinochloa crus-galli $(L)$. & Grass & A & Poaceae \\
3. & Eragrostis japonicum & & & \\
II. & Sedges & Umbrella plant & A & Cyperaceae \\
1. & Cyperus difformis & Rice flat sedge & A & Cyperaceae \\
2. & Cyperus iria & & & \\
III. & Broad leaved weeds & Red stem & A & Lythraceae \\
1. & Ammania baccifera & False daisy & A & Asteraceae \\
2. & Eclipta prostrate & Neer kirambu in Tamil & A & Onagraceae \\
3. & Ludwigia parviflora Roxb & The water fern & P & Marsileaceae \\
\hline 4. & Marselia quadrifoliata & & &
\end{tabular}

A- Annual; P- Perennial

sodium is the early post emergence herbicide had the injury symptoms on weeds. The symptoms begin as chlorosis and stop the growth of weeds after 3 to 5 days of treatment. Necrosis begins after 5 days of treatment and plant death was occurred within 10 days treatment. Valent, 2003 reported that necrosis was occurring after 3 days of treatment and plant death occurred within 15 days of treatment. At $60 \mathrm{DAS}$, the data clearly indicated that higher dose of bispyribac sodium $10 \%$ SC with 40 $\mathrm{g} \mathrm{ha}{ }^{-1}$ have effectively controlled the weeds. Mean while pretilachlor + safener is quite safe and can be effectively used for weed control in sprouted rice during initial period without harming rice seedlings (Anonymous, 1999). Crop safety and superior weed control in direct seeded puddled rice with sofit on 3 DAS was reported by Reddy (2010).

Nutrient removal by weeds

Nitrogen removal by weeds: There was significant reduction in $\mathrm{N}$ depletion by weeds among different weed management practices. The efficiency of the weed control treatment and the nutrient uptake by weeds was negative to each other (Table.3). Weed free check registered significantly the lowest uptake of $\mathrm{N}$ by eeds. Among the treatments, application of bispyribac sodium $10 \% \mathrm{SC}$ at 40 $\mathrm{g} \mathrm{ha}^{-1}\left(\mathrm{~T}_{3}\right)$ recorded the lowest nitrogen uptake by weeds at all the stages of observation with $1.5,3.1$ and $5.1 \mathrm{~kg} \mathrm{ha}^{-1}$ on 20, 40 nd 60 DAS respectively. This treatment was on par with application of pretilachlor $S$ at $0.45 \mathrm{~kg}$ a.i ha ${ }^{-1}$ with one hand weeding on 40 DAS $\left(\mathrm{T}_{7}\right)$ on 40 and 60 DAS. Unweeded control $\left(\mathrm{T}_{12}\right)$ registered highest $\mathrm{N}$ uptake through weeds due to lack of weed control. Similar finding was reported by Sanjay et al. (2006) with $\mathrm{N}$ uptake of $25.1 \mathrm{~kg} \mathrm{ha}^{-1}$ by weeds in unweeded plots. Revathi (2009) found that lower weed density and weed dry matter in direct planting system which entailed lower $\mathrm{N}$ removal by weeds.

Phosphorus removal by weeds: Significant variations were observed among treatments in reducing the uptake of $\mathrm{P}$ by weeds. Similar to $\mathrm{N}$ uptake by weeds, the $\mathrm{P}$ uptake was significantly lesser in weed free check at all stages of observation. Among the weed management treatments application of bispyribac sodium $10 \% \mathrm{SC}$ at $40 \mathrm{~g}$ a.i. $\mathrm{ha}^{-1}\left(\mathrm{~T}_{3}\right)$ recorded low $\mathrm{P}$ uptake by weeds with $0.13,0.24,0.40 \mathrm{~kg} \mathrm{ha}^{-1}$ on $20,40,60$ DAS respectively (Table.3). On 40 DAS, bispyribac sodium $10 \%$ SC at $40 \mathrm{~g}$ a.i. $\mathrm{ha}^{-1}\left(\mathrm{~T}_{3}\right)$ was on par with pretilachlor $\mathrm{S}$ at 0.45 $\mathrm{kg}$ a.i $\mathrm{ha}^{-1}+$ one hand weeding on 40 DAS $\left(\mathrm{T}_{7}\right)$, pre-emergence herbicide butachlor EW $50 \%$ at $1.5 \mathrm{~kg}$ ha + one hand weeding on 40 DAS $\left(\mathrm{T}_{5}\right)$, anilophos $30 \%$ $\mathrm{EC}$ at $0.45 \mathrm{~kg} \mathrm{ha}^{-1}+$ one hand weeding on 40 DAS $\left(\mathrm{T}_{6}\right)$, early post-emergence herbicide bispyribac sodium $10 \%$ SC $20 \mathrm{~g} \mathrm{ha}^{-1}\left(\mathrm{~T}_{2}\right)$, nominee gold $10 \%$ SC $20 \mathrm{~g} \mathrm{ha}^{-1}\left(\mathrm{~T}_{4}\right)$.

On 60 DAS, pretilachlor $S$ at $0.45 \mathrm{~kg}^{\mathrm{a}} \mathrm{i} \mathrm{ha}^{-1}+$ one hand weeding on 40 DAS $\left(\mathrm{T}_{7}\right)$ was on par with anilophos $30 \% \mathrm{EC}$ at $0.45 \mathrm{~kg} \mathrm{ha}^{-1}+$ one hand weeding on 40 DAS $\left(\mathrm{T}_{6}\right)$, butachlor $50 \% \mathrm{EW}$ at $1.5 \mathrm{~kg} \mathrm{ha}^{-1}+$ one hand weeding on 40 DAS $\left(\mathrm{T}_{5}\right)$ and cono weeder weeding on 20 and 40 DAS $\left(\mathrm{T}_{10}\right)$. Madhu and Nanjappa (1997) studied that substantial removal of N, P and $\mathrm{K}$ by weeds in unweeded plots and corresponding saving in nutrients with effective weed control treatments. Bispyribac sodium $10 \% \mathrm{SC}$ at $40 \mathrm{~g}$ a.i. $\mathrm{ha}^{-1}\left(\mathrm{~T}_{3}\right)$ recorded lower NPK removal by weeds because of lower weed dry weight. This result is in accordance with the findings of Singh et al. ( 2007) who reported that the nutrient removal by weeds was minimum with low fertility level and it increased with the fertility level.

Potassium removal by weeds: Similar to $\mathrm{P}$ uptake, $\mathrm{K}$ uptake was also in the same trend on 20 and 40 DAS. Weed free check has the lowest uptake of 1.15 and $2.90 \mathrm{~kg} \mathrm{ha}^{-1}$ on 20 and 40 DAS respectively and significantly superior to other treatments (Table.3). On the same days of observation bispyribac sodium $10 \%$ $\mathrm{SC}$ at $40 \mathrm{~g}$ a.i. $\mathrm{ha}^{-1}\left(\mathrm{~T}_{3}\right)$ was on par with pretilachlor $\mathrm{S}$ on 40 DAS $\left(\mathrm{T}_{7}\right)$. At the later stage of crop growth $(60$ DAS) weed free check was on par with bispyribac 
Table 3. Effect of weed management practices on nutrient uptake $\left(\mathrm{kg} \mathrm{ha}^{-1}\right)$ by weeds.

\begin{tabular}{|c|c|c|c|c|c|c|c|c|c|}
\hline \multirow[b]{2}{*}{ Treatments } & \multicolumn{3}{|c|}{ Nitrogen uptake $\left(\mathrm{kg} \mathrm{ha}^{-1}\right)$} & \multicolumn{3}{|c|}{ Phosphorus uptake $\left(\mathrm{kg} \mathrm{ha}^{-1}\right)$} & \multicolumn{3}{|c|}{ Potassium uptake $\left(\mathrm{kg} \mathrm{ha}^{-1}\right)$} \\
\hline & $\begin{array}{c}20 \\
\text { DAS }\end{array}$ & $\begin{array}{c}40 \\
\text { DAS }\end{array}$ & $\begin{array}{c}60 \\
\text { DAS }\end{array}$ & $\begin{array}{c}20 \\
\text { DAS }\end{array}$ & $\begin{array}{c}40 \\
\text { DAS }\end{array}$ & $\begin{array}{c}60 \\
\text { DAS }\end{array}$ & $\begin{array}{c}20 \\
\text { DAS }\end{array}$ & $\begin{array}{c}40 \\
\text { DAS }\end{array}$ & $\begin{array}{c}\text { 60 } \\
\text { DAS }\end{array}$ \\
\hline $\mathrm{T}_{1}$ & 7.5 & 8.9 & 14.3 & 0.55 & 0.61 & 10.1 & 11.33 & 15.00 & 18.10 \\
\hline $\mathrm{T}_{2}$ & 5.0 & 7.6 & 10.1 & 0.32 & 0.41 & 0.6 & 9.36 & 12.59 & 13.00 \\
\hline $\mathrm{T}_{3}$ & 1.5 & 3.1 & 5.1 & 0.13 & 0.24 & 0.4 & 1.90 & 3.50 & 5.90 \\
\hline $\mathrm{T}_{4}$ & 5.4 & 7.7 & 10.9 & 0.39 & 0.48 & 0.7 & 9.40 & 12.50 & 12.94 \\
\hline $\mathrm{T}_{5}$ & 4.4 & 6.7 & 9.6 & 0.27 & 0.36 & 0.6 & 7.42 & 7.00 & 10.00 \\
\hline $\mathrm{T}_{6}$ & 4.2 & 6.9 & 9.7 & 0.25 & 0.37 & 0.5 & 7.50 & 7.20 & 10.30 \\
\hline $\mathrm{T}_{7}$ & 1.7 & 3.4 & 5.4 & 0.19 & 0.27 & 0.5 & 2.20 & 3.60 & 6.20 \\
\hline $\mathrm{T}_{8}$ & 7.6 & 8.4 & 14.1 & 0.58 & 0.62 & 1.1 & 11.55 & 15.07 & 18.40 \\
\hline $\mathrm{T}_{9}$ & 7.9 & 8.6 & 14.7 & 0.57 & 0.67 & 1.1 & 11.29 & 14.95 & 18.20 \\
\hline $\mathrm{T}_{10}$ & 4.7 & 6.7 & 9.8 & 0.29 & 0.31 & 0.6 & 7.27 & 7.01 & 10.10 \\
\hline $\mathrm{T}_{11}$ & 0.4 & 0.6 & 0.9 & 0.01 & 0.03 & 0.1 & 1.15 & 2.90 & 5.90 \\
\hline $\mathrm{T}_{12}$ & 8.9 & 10.7 & 18.7 & 0.78 & 0.89 & 1.8 & 14.17 & 19.00 & 20.50 \\
\hline SED & 0.08 & 0.18 & 0.23 & 0.007 & 0.13 & 0.12 & 0.25 & 0.53 & 0.32 \\
\hline $\mathrm{CD}(\mathrm{P}=0.05)$ & 0.18 & 0.38 & 0.47 & 0.014 & 0.28 & 0.26 & 0.53 & 0.27 & 0.67 \\
\hline
\end{tabular}

sodium $10 \% \mathrm{SC}$ at $40 \mathrm{~g}$ a.i. $\mathrm{ha}^{-1}\left(\mathrm{~T}_{3}\right)$ and pretilachlor $\mathrm{S}$ at $0.45 \mathrm{~kg} \mathrm{a.i} \mathrm{ha-1}+$ one hand weeding on $40 \mathrm{DAS}\left(\mathrm{T}_{7}\right)$. Rana and Angiras (1999) confirmed that N, P and K removal by weeds was limited in herbicide applied plots compared to unweeded control. Due to uncontrolled weed growth, the removal of $\mathrm{N}, \mathrm{P}$ and $\mathrm{K}$ by the weeds was highest in the unweeded check which resulted in increased drymatter production of weeds.

Grain yield : Since, different weed management practices did exert significant influence on growth and yield attributes of rice crop, it reflected on grain yield also. As in the weed control efficiency higher, the grain

Table 4. Effect of weed management practices on residual crop of green gram (Mean of three replications).

\begin{tabular}{|c|c|c|c|c|c|}
\hline \multirow{2}{*}{$\begin{array}{l}\text { S. } \\
\text { N. }\end{array}$} & \multirow[t]{2}{*}{ Treatments } & \multirow{2}{*}{$\begin{array}{c}\text { Germination } \\
(\%)\end{array}$} & \multicolumn{2}{|c|}{ Plant height $(\mathrm{cm})$} & \multirow{2}{*}{$\begin{array}{c}\text { Grain } \\
\text { yield } \\
\left(\mathrm{kg} \mathrm{ha}^{-1}\right)\end{array}$} \\
\hline & & & 20 DAS & 40 DAS & \\
\hline $\mathrm{T}_{1}$ & EPOE bispyribac sodium $10 \% \mathrm{sc}$ at $10 \mathrm{~g}$ a.i./ha ${ }^{-1}$ & 95.89 & 25.89 & 45.00 & 555 \\
\hline $\mathrm{T}_{2}$ & EPOE bispyribac sodium $10 \% \mathrm{sc}$ at $20 \mathrm{~g}$ a.i. $/ \mathrm{ha}^{-1}$ & 96.00 & 26.93 & 46.32 & 562 \\
\hline $\mathrm{T}_{3}$ & EPOE bispyribac sodium $10 \% \mathrm{sc}$ at $40 \mathrm{~g}$ a.i. $/ \mathrm{ha}^{-1}$ & 98.13 & 26.93 & 48.29 & 588 \\
\hline $\mathrm{T}_{4}$ & $\begin{array}{l}\text { EPOE bispyribac sodium (nominee gold) } 10 \% \mathrm{sc} \\
\text { at } 20 \mathrm{~g} \text { a.i. } / \mathrm{ha}^{-1}\end{array}$ & 96.00 & 26.60 & 46.25 & 564 \\
\hline $\mathrm{T}_{5}$ & PE butachlor at $1.5 \mathrm{~kg}$ a.i. $/ \mathrm{ha}^{-1}+\mathrm{hw}$ on 40 das & 97.20 & 26.47 & 47.32 & 572 \\
\hline $\mathrm{T}_{6}$ & PE anilophos at $0.45 \mathrm{~kg}$ a.i. $/ \mathrm{ha}^{-1}+\mathrm{hw}$ on 40 das & 97.00 & 26.63 & 47.07 & 570 \\
\hline $\mathrm{T}_{7}$ & PE pretilachlor s at $0.45 \mathrm{~kg}$ a.i. $/ \mathrm{ha}^{-1}+\mathrm{hw}$ on 40 das & 97.00 & 26.87 & 48.12 & 587 \\
\hline $\mathrm{T}_{8}$ & Power weeder on 20 and 40 DAS & 96.26 & 25.17 & 45.60 & 555 \\
\hline $\mathrm{T}_{9}$ & Cono weeder on 20 and 40 DAS & 96.00 & 26.43 & 45.80 & 554 \\
\hline $\mathrm{T}_{10}$ & Hand weeding on 20 and 40 DAS & 97.33 & 26.83 & 47.06 & 574 \\
\hline $\mathrm{T}_{11}$ & Weed free check & 99.27 & 26.47 & 48.33 & 595 \\
\hline $\mathrm{T}_{12}$ & Weedy Check & 99.00 & 25.00 & 46.23 & 560 \\
\hline
\end{tabular}




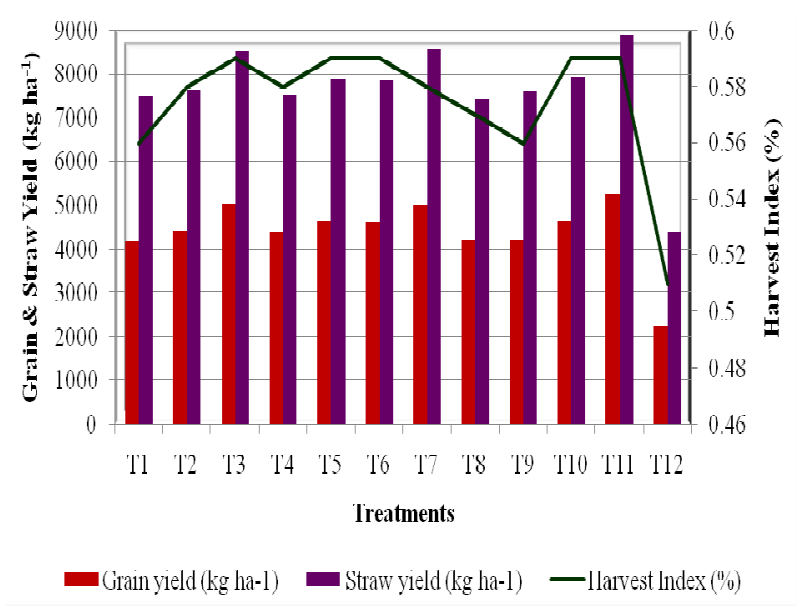

Fig. 1. Effect of weed management practices on grain yield $\left(\mathrm{kg} \mathrm{ha}^{-1}\right)$, straw yield $\left(\mathrm{kg} \mathrm{ha}^{-1}\right)$ and Harvest Index (\%) of rice.

yield was significantly recorded by weed free check $5268 \mathrm{~kg} \mathrm{ha}^{-1}$. It was 135.26 per cent higher than weedy check and 13.15 per cent higher than hand weeding twice 20 and 40 DAS (farmer's method) which recorded $4655 \mathrm{~kg} \mathrm{ha}^{-1}$ (Fig.1). Among the weed management treatments, EPOE bispyribac sodium $10 \% \mathrm{SC}$ at $40 \mathrm{~g}$ $\mathrm{ha}^{-1}\left(\mathrm{~T}_{3}\right)$ recorded as high of $5058 \mathrm{~kg} \mathrm{ha}^{-1}$ grain yield and was on par with pretilachlor $\mathrm{S}$ at $0.45 \mathrm{~kg}$ a.i ha ${ }^{1}$ as pre-emergence + one hand weeding on 40 DAS $\left(\mathrm{T}_{7}\right)$ which recorded $5005 \mathrm{~kg} \mathrm{ha}^{-1}$. Earlier treatment has registered 8.65 per cent and later registered 7.51 per cent higher grain yield over hand weeding twice on 20 and 40 DAS $\left(\mathrm{T}_{10}\right)$. Butachlor $50 \% \mathrm{EW}+$ one hand weeding on 40 DAS (T5) and anilophos $30 \% \mathrm{EC}+$ one hand weeding on 40 DAS $\left(\mathrm{T}_{6}\right)$ recorded the grain yield with 0.01 and 0.49 per cent lesser grain yield than hand weeding twice on 20 and 40 DAS $\left(\mathrm{T}_{10}\right)$. Where as in the mechanical weed control method with power weeder (4218 kg ha-1) and manually operated cono weeder $\left(4221 \mathrm{~kg} \mathrm{ha}^{-1}\right)$ recorded 9.37 and 9.31 per cent lesser grain yields than hand weeding twice on 20 and 40 DAS. But they have recorded significantly higher yield than weedy check.

Application of bispyribac sodium $10 \% \mathrm{SC}$ at $20 \mathrm{~g} \mathrm{ha}^{-1}$ $\left(\mathrm{T}_{2}\right)$ and bispyribac sodium $10 \% \mathrm{SC}$ at $10 \mathrm{~g} \mathrm{ha}^{-1}\left(\mathrm{~T}_{1}\right)$ recorded the grain yield of $4419 \mathrm{~kg} \mathrm{ha}^{-1}$ and $4196 \mathrm{~kg} \mathrm{ha}^{-1}$ respectively, which were 12.6 and 17.0 per cent lesser than bispyribac sodium $10 \% \mathrm{SC}$ at $20 \mathrm{~g} \mathrm{ha}^{-1}\left(\mathrm{~T}_{2}\right)$. The available early post-emergence in the market Nominee gold $10 \% \mathrm{SC}$ at $20 \mathrm{~g}$ ai/ha $\left(\mathrm{T}_{4}\right)$ application registered $4393 \mathrm{~kg} \mathrm{ha}^{-1}$ which was 13.1 per cent lesser grain yield than bispyribac sodium $10 \% \mathrm{SC}$ at $40 \mathrm{~g} \mathrm{ha}^{-1}\left(\mathrm{~T}_{3}\right)$. Veeraputhiran and Balasubramanian (2010) reported that the application of bispyribac sodium at $50 \mathrm{~g}$ a.i. $\mathrm{ha}^{-1}$ recorded the highest grain yield. This was attributed to the favourable condition created through efficient weed control which resulted in lesser weeds competition to the crops.

Straw yield: Similar to grain yield, straw yield was also influenced significantly by different weed management practices (Fig.1). Weed free check recorded the highest straw yield of $8900 \mathrm{~kg} \mathrm{ha}^{-1}$ which was on par with integraded weed management method of pre-emergence application of pretilachlor at $0.45 \mathrm{~kg}$ a.i. $\mathrm{ha}^{-1}+\mathrm{HW}$ at 40 DAS (8600 $\mathrm{kg} \mathrm{ha}^{-1}$ ) and early post-emergence herbicide application of bispyribac sodium $10 \%$ SC at $40 \mathrm{~g} \mathrm{ha}^{-1}\left(8520 \mathrm{~kg} \mathrm{ha}^{-}\right.$ $\left.{ }^{1}\right)$. Unweeded check recorded significantly low straw yield of $4389 \mathrm{~kg} \mathrm{ha}^{-1}$. Yield losses of similar magnitude due to weed competition have been reported by Rajendra kumar (2003). Reddy (2010) recorded higher straw yield with direct planting system due to effective suppression of weeds, less nutrient removal by weeds and higher nutrient uptake by crop.

Harvest index: Different weed management practices failed to reach the level of significance in influencing the harvest index (Fig.1). However, the maximum harvest index of 0.59 was recorded by early post-emergence herbicide application of bispyribac sodium $10 \%$ SC at $40 \mathrm{~g} \mathrm{ha}^{-1}\left(\mathrm{~T}_{3}\right)$, pre-emergence application of butachlor at $1.5 \mathrm{~kg}$ a.i. $\mathrm{ha}^{-1}+\mathrm{HW}$ at $40 \mathrm{DAS}\left(\mathrm{T}_{5}\right)$, anilophos at $0.45 \mathrm{~kg}$ a.i. $/ \mathrm{ha}^{-1}+\mathrm{HW}$ on 40 DAS $\left(\mathrm{T}_{6}\right)$, hand weeding on 20 and 40 DAS and weed free check $\left(\mathrm{T}_{11}\right)$.

Residual effect of herbicide on succeeding crop of green gram

Germination percentage: The different weed management practices did not affect the germination percentage of succeeding crop of green gram. It ranged from 95.89 to 98.13 per cent (Table.4).

Plant height: No much difference was observed on plant height of green gram on 20 and 40 DAS due to different weed management practices on rice crop (Tanble.4).

Grain yield: Since, the germination and plant height of green gram were not altered by the weed management practices on rice crop, the grain yield of green gram has not shown much difference (Table.4). Srinivasan and Pothiraj (1989) found that the residual effect of weed control methods significantly influenced the succeeding green gram yield. Yadav et al. (2010) also reported that application of bispyribac sodium at $60 \mathrm{~g}$ a.i. ha ${ }^{-1}$ had no residual toxicity on succeeding crop of wheat.

\section{Conclusion}

The results of this experiment revealed that among the weed management practices application of early post emergence herbicide bispyribac sodium 10\% SC $40 \mathrm{~g}$ $\mathrm{ha}^{-1}\left(\mathrm{~T}_{3}\right)$ recorded higher grain yield of $5058 \mathrm{~kg} \mathrm{ha}^{-1}$ and lower NPK uptake by weeds. Application of bispyribac sodium $10 \%$ SC at different doses did not have any phytotoxicity effect on succeeding crop of green gram. Hence bispyribac sodium $10 \% \mathrm{SC}$ at $40 \mathrm{~g}$ a.i. ha ${ }^{-1}$ as early post emergence herbicide was found to be an effective and alternative post emergence herbicide for better weed control, higher grain yield and economic returns in direct seeded lowland rice.

\section{REFERENCES}

Anonymous (1999). Training manual. Training Programme on Farm machinery for the benefit of Officers of the 
Karnataka State Department of Agricultural, published by University of Agricultural Sciences, Bangalore.

Bayan, H.C. (2000). Studies on integrated weed management under split application of nitrogen in wet seeded rice. Ph.D. Thesis, Tamil Nadu Agric. Univ., Coimbatore.

Choubey, N.K., Kolhe, S.S. and Tripathi, R.S. (2001). Relative performance of cyhalofop butyl for weed control in direct seeded rice. Indian J. Weed Sci., 33(3 \& 4): 132-135.

FAO (2010). World rice production status. Food and Agricultural Organisation .

Madhu, M. and Nanjappa, H.V. (1997). Nutrient uptake by crop and weeds as influenced by weed control treatment in puddled seeded rice. Crop Res. (Hissar), 13(1): 1-6.

Pandey, M.P., Verulkar, S.B. and Sharma, D. (2010). Rice research: past achievements, present scenario and future thrust. Indian Journal of Agric. Sci., 80(6):447-69.

Ravisankar, N. 2002. Efficacy of seeling methods, in situ incorporation of Daincha and application time of pretilachlor plus on weed management and productivity of wet seeded rice. Ph.D. Thesis, Tamil Nadu Agric. Univ., Coimbatore.

Prakash, H.C., Shekara, B.G., Jahadeesh, B.R., Kalayanmurthy, KN. and Sivalingam, M.L. (2008). Paddy pulse cropping system for sustaining soil health and rice yield in Cavery command area. Res. On Crops, 9(1):7-9.

Rajendra Kumar. B. (2003). Studies on weed management in anaerobic tolerant rice cultivars under direct wet seeded condition. M.Sc. Thesis. Tamil Nadu Agric. Univ., Coimbatore.

Rana, S.S. and Angiras, N.N. (1999). Influence of integrated weed management practices on weed competition for nutrients in puddle sown rice. Indian J. Weed Sci., 31 (3 and 4): $161-163$.

Reddy, G.S. (2010). Integrated weed management in drum seeding and direct planting system. M.Sc. (Ag.) Thesis. Tamil Nadu Agricultural University, Coimbatore, Tamil Nadu, India.
Revathi, A. 2009. Establishment techniques and weed management practices in puddled lowland rice. M.Sc. (Ag.) Thesis. Tamil Nadu Agricultural University, Coimbatore, Tamil Nadu, India.

Sanjay, M.T., Shetty, P.T.K. and Nanjappa, H.V. (2006). Influence of weed management practices on nutrient uptake and productivity of rice under different methods of crop establishment. Crop Res., 32: pp.131-136.

Singh, P., P. Singh and S.S. Singh. (2007). Response of aromatic rice (Pusa Basmati 1) to establishment methods, fertility levels and weed management practices. Indian J. Weed Sci. 39(1\&2):32-35

Srinivasan, G. and Pothiraj (1989). Evaluation of herbicide mixtures for weed control in transplanted rice-pulse cropping system. Madras Agric. J., 76(2): pp. 66-72.

Subramanian, E., James Martin, G. and Balasubramanian, R. (2006). Effect of integrated weed management practices on growth and yield of wet seeded rice (Oryza sativa) and their residual effect on succeeding pulse crop. Indian J. Agron., 51(2): 93-96.

Valent USA. (2003). Regiment herbicide approved surfactants for use with Regiment. Walnet Crrek, CA: Valent USA Corp. 6.

Veeraputhiran, R. and R. Balasubramanian (2010). Evaluation of new post emergence herbicide in transplanted rice. In: Proc. of Annual Weed Science Conf., $30^{\text {th }}$ November \& $1^{\text {st }}$ December, TNAU, Coimbatore. P.175.

Yadav, D.B., Ashok Yadev and Punia, S.S. (2009). Evaluation of bispyribac sodium for control in transplanted rice. Indian J. Weed Sci., 41(1\&2): 23-27.

Yadav, D.B., Punia, S.S. and Ashok Yadav (2010). Efficacy of bispyribac sodium, azimsulfuron and penoxsulam for post emergence weed control in transplanted rice. In: Proc. Of Biennial Weed Science Conf., $26^{\text {th }}$ February, Indira Gandhi Krishi Vishwavidyalaya, Raipur. P.85. 